\title{
Teaching Transitional Justice: Towards a Political and Personal Transformative Journey
}

\author{
Gertrude Fester-Wicomb
}

\begin{abstract}
In reflecting on my teaching experience of transitional justice i realised that it was not just an academic exercise but a deeply spiritual, political and personal journal for many of my students and me. In introducing myself as a South African former political prisoner there was what i felt some immediate empathy and rapport. In this chapter $i$ will trace sharing new learnings, apprehension, pain, celebration and hope. Intimately encountering the comprehensive spirit of reconciliation in my class and Rwanda, it encouraged a personal journey conjuring up courage to communicate with my torturer/interrogator exploring possibilities of reconciliation.
\end{abstract}

In reflecting on my teaching experience of Module 607 Transitional Justice mainstreaming Gender $(\mathrm{TJ}) \mathrm{i}^{1}$ realised that it was not just an academic exercise but also a deeply spiritual, political and personal journal for many of my students and me. This is evident from the responses of the students to the evaluation i conducted with them. ${ }^{2}$ The official evaluation done by the university is also evidence of this. I will be quoting from my questionnaire and let the voices of the students be foregrounded. In introducing myself to

How to cite this book chapter:

Fester-Wicomb, G. 2021. Teaching Transitional Justice: Towards a Political and Personal Transformative Journey. In: Randell, S., Yerbury, H. and Escrig-Pinol, A. (eds.) Gender and Learning in Rwanda. Pp. 65-75. Sydney: UTS ePRESS. DOI: https://doi.org/10.5130/aag.f. License: CC BY-NC-ND. 
the class as a South African, from the subsequent discussions and questions i straightaway sensed that they knew about the struggles in my country. There seemed to be an identification with me as also having experienced conflict and oppression. Most of them knew about Nelson Mandela and aspects of his life. In elaborating that $\mathrm{i}$ was a former political prisoner i felt immediate empathy.

In this chapter i will trace the sharing, new learnings, apprehension, pain, celebration and hope. Intimately encountering the comprehensive spirit of reconciliation in my class, just living in Rwanda and learning and exchanging perspectives with my students encouraged in me a personal journey conjuring up courage to communicate with my torturer/interrogator from Apartheid South Africa (SA) and exploring possibilities of reconciliation.

Firstly, i will highlight aspects of my lessons and the responses that i had had. Thereafter will be the students' evaluation according to my questionnaire. My approach was qualitative and hence more feminist in that the students could share their personal feelings and emotions. I will use the students' direct words and give each a number, not using their names even though they had given permission for their names to be used. I had committed that before $\mathrm{i}$ used their work with their names attached i would share it with them. Now it is not possible to share this writing with all of them, hence they will all remain anonymous. I also would like to stress that although i was the teacher/lecturer, the experience for me was one of profound reciprocation. I have learnt from them as much as they probably have learnt from me. For this i thank them. I also am grateful to Professor Shirley Randell for her vision and insight in almost single-handedly establishing this Centre for Gender. She also gave me the opportunity to be part of this wonderful experience of teaching in Rwanda. I will conclude with the summary of my findings and my analysis of them. Thereafter i will share my interaction with my interrogator/torturer and the subsequent events after my approaching him and then I will conclude.

My teaching methodology was mixed. It ranged from formal lectures and the use of PowerPoints to games, quizzes, panel discussions, presentations, drama, and i hoped that i was successful in implementing what Paulo Freire advocated in his Pedagogy of the Oppressed. I also often re-arranged the lecture style of the desks into a circle to facilitate communication more effectively with all the students facing one another. There also were some amazing magical moments when the class spontaneously burst into song and even did their elegant Rwandan dance.

For my very first lesson we stood in a circle and they each had to introduce themselves, do a movement if they felt comfortable and also share their favourite animal. One of the aspects that i was acutely aware of was that often some students did not feel comfortable with drama and movements in the class. Hence i always added that they should feel comfortable and participate as it suited them. It was during this exercise that $\mathrm{i}$ understood the importance of cows to Rwandans. Almost $90 \%$ of the class shared that the cow was their favourite animal. 
I was conscious of the fact that most of the students did not have English as their first language. When $i$ am excited i tend to speak fast. I mentioned this to them and appealed to them to please indicate when i speak too fast or whether they do not understand. This happened a few times that student brought this to my attention. However, in the evaluation there was one who commented on this. It may mean that i was not completely successful in slowing down altogether and that that this person did not feel comfortable in asking me to slow down. I acknowledge this weakness of mine.

In keeping with sound classroom management, the need for maximum empowerment, building of confidence of students and the Freirean education as a liberatory tool, i always endeavoured to encourage maximum class participation. Drama is well known to be an effective method to facilitate personal growth and development as well as confidence building. Hence this was used frequently and where appropriate, once again bearing in mind there may be those who would not like to participate. No one was ever compelled to participate in the drama. However, soon all of them were happily and actively engaged in their performances on some or other scenario around conflict and resolutions.

As stated earlier there were times that i had formal lectures as an introduction to the topic. Nonetheless, I preferred to have interactive exchanges. I would occasionally ask different students to comment or raise questions. Thus, during the early stages i one day asked a particular student a question. The entire class (or so it seemed) sniggered or burst out laughing. I was shocked at this behaviour and tried diplomatically to assess what the issue was. However, i was rather stern in my critique of their laughter. I reminded them that their behaviour went against the entire grain of TJ and the respect for the dignity and integrity of each individual. I then realised that this student was French and Kinyarwanda speaking and his English was minimal. I then repeated my question to him more slowly but there was no response. I reformulated my statement in various ways in order to simplify it. Eventually i restated my question as a statement. I then asked the student whether he agreed or disagreed with my statement. I further encouraged him by requesting: 'Just say "yes" or "no"'. He then said 'No'. In subsequent lessons i sometimes engaged this student in a similar fashion until i augmented the interaction to use further sentences. I added, 'Why do you agree?' This student gradually spoke extemporaneously, interacted actively in discussions and his presentations were well prepared. ${ }^{3}$ He was one of the first students to complete and submit his thesis. I recall that during his viva he performed very well.

I was also mindful of the fact that our students had had a long day of work before coming to class at $6 \mathrm{pm}$ until $9 \mathrm{pm}$. I heard that most places of work commence at $7 \mathrm{am}$ until 5pm. These long hours were of concern and that there was no time for relaxation or exercises. I then decided to institute some relaxation exercises like stretches or that we should maybe jog or walk briskly 
around the classroom block sometimes. There were a few who adamantly refused to participate. I tried to encourage them on the importance of exercises but to no avail. This i accepted. On the other hand, i also introduced meditation; both guided and unguided. I recall some students thanked me in the evaluation for introducing them to meditation.

\section{Students' Reflections}

The following is based on an evaluation for TJ for the class done on 29 July 2011. The written questions posed to the students were optional and they responded in writing to a questionnaire with open-ended questions. The quotations will be used verbatim. The references for each student are devised as follows: $\mathrm{S}$ for the group, then the group number followed by the students' comments which had been transcribed and numbered. Students were also given the option to write their names on the questionnaire. I will focus mainly on the responses to questions 3 and 4 as they directly link to the theme of this chapter.

Question 3 asked: 'Did you find the content sometimes upset you, made you angry or caused pain and anguish? In general how did it affect you emotionally?'

The data from responses can be divided into the following themes: (1) not experienced any emotions; (2) very angry with what's happened and still is happening in some countries; (3) victim vs perpetrator; (4) questioning why is it important to learn and some gender implications.

Some general responses on each of these themes are presented below. Responses on theme one were as follows:

- The content did not affect me emotionally because as ... scholar(s) we have to do analysis. (S3.16).

- Not at all (S3.8).

- No, the content was very interesting (S3.14).

The responses above are the only three from the 38 students in the class to have used this theme in their response which meant that the majority of the class had been emotionally affected.

From theme 2, most of the students referred to the issue of justice hence the subject content made an impact on them. Some were affected by injustice even within TJ mechanisms and expressed this:

- I have been emotionally affected by the way injustice is still affecting millions of people all over the world despite efforts (S3.34). 
- It did not affect my emotional status but sometimes when we were reading [about] other countries I was sometimes very upset by the way they are very unjust. (S3.29).

There was also some focus on the third theme, victim versus perpetrator:

- Studying about the elements of TJ like reparations ... and compensation remind me of the life between survivors and perpetrators ... sometimes it was a painful experience (S3.30).

- As a survival [survivor] of Genocide, I found teaching [reading] the way the persecutors are given money in Ugandan Amnesty Act and it made me think about what victims feels (S3.37).

- I was very upset and angry about the failure for TJ to benefit victims fully (S3.35).

Students understood the inequality of how victims and perpetrators had been unfairly treated. At one stage a student stated out of the blue that perpetrators are everywhere in the country, they only have not been exposed. He added: 'In fact here could be perpetrators right in this class.' There was an awkward silence and momentarily i was at a loss of what to say. On gaining my composure $\mathrm{i}$ referred to the remarkable success thus far in Rwanda and how Rwandans have inspired the world with their forgiveness and reconciliation. A discussion then followed regarding the way forward.

The follow-up part of question 3 asked: 'Why do you think it is important to learn about TJ?’ Some responses highlighted gender implications:

- I feel bad to know how war and post-war affect women differently with [from] men. (S3.3).

- Yes, TJ teaches me how to respect all people irrespective of status, e.g. gender, race, ethnic[ity] (S4.27).

Question 4 asked: 'Did you encounter that through learning about TJ you had to reflect on your own behaviour?'

The data from the responses can be classified into the following five themes: (1) Yes, they reflected or (2) their behaviour changed; (3) expression of commitment to peace and gender issues; (4) awareness of being integral to TJ; (5) reflection on behaviour/revelation/ realisation.

Most responses were couched in general terms but one gave details of specific lessons. I used the song of South African singer, Vicki Sampson, 'My African Dream'. I played the song a few times so that they could clearly hear and understand all the words. The students then had to reflect on their Dream for Rwanda. Another lesson referred to was that of what type of Rwanda they want 
to work towards. They then had to write a letter to the children of Rwanda. To the question, one student wrote the following:

- Yes, [I reflected on my behaviour] several times and especially with the exercises of 'My Rwandan Dream' and 'A letter to the Children of Rwanda'. (S4.1).

Others made reference to peace building and gender issues:

- Yes, I found the opportunity to think about my own behaviour, what was my role in the process of peace and reconciliation in my country, and i discovered what $\mathrm{i}$ had to do in order to live (having) good relationships with others (S4.13).

- Justice is a prerequisite for sustainable peace and reconciliation and gender [analysis] is the only way as a human rights issue, but also as a way of ensuring success and sustainability (S 1.11).

- I am a peace builder every moment of my life at work when i resolve cases of gender-based violence between spouses, as a staff member of the gender monitoring office (S3.12).

Students used the vocabulary of TJ like Justice, sustainable peace and were thus acquainted with the concepts, but they also applied these to their own lives at their places of work and their homes. Teaching TJ and being exposed to horrific situations which had occurred really shocked us all. Some students shared how they were emotionally affected:

- When we were analysing some articles such as human rights reports about the Rwanda Gacaca courts it was painful ... (S3.4).

- The content sometimes made me upset and caused pain (S3.12).

Some reflected on their behaviour and their role as change agents:

- I ... realise how I can be a peace builder wherever I am (S3.4).

- Yes, peace is first and foremost. As an individual obligation, the world's peace begins with me as an individual (S3.10).

Other examples of this reflection resulted in their commenting on working towards some change in their lives:

- This course of TJ helped me to reflect on my behaviour that I should avoid conflict starting with me in my home (S3.5).

- I learnt a lot from TJ. I had to think of my way of forgiving, peace building, reconciliation, etc. (S3.11). 
- With the TJ Course, I got the chance to examine my conscience and realise I need to operate some changes in behaviour, respect ... others and [be] responsible (S3.15).

- Yes, I had always to reflect on my own behaviour-some exercises also required one to think about our own behaviour. Yes, I believe I treat [colleagues and workers] with respect (S3.19).

These responses reflect what i stated at the beginning of this chapter: That TJ was not just an academic exercise but a personal journey in many ways.

One of the key lessons we focused on was to learn to be critical and read texts critically. At various workshops in Kigali, Rwandan scholar, Phil Clarke, emphasised how polarised academics are about Rwanda and the progress developing: some called President Paul Kagame a dictator whereas others saw him as visionary. What we discovered when we did literature searches on the internet was that the majority of the texts on the internet or even in the library were written by non-Rwandans. This we discussed and came to the conclusion why it is important for Rwandans to publish their research. We discussed this as an epistemological issue. Some writers have never even been in Rwanda and used secondary data done by non-Rwandans. We looked at their research methodology and the periods that they actually did their fieldwork. Some had very small samples and most none at all, yet they made the most generalised comments in a most authoritative and confident manner. ${ }^{4}$ The students were concerned about this:

- Yes, sometimes the content was making me angry because the articles and publications had different and inaccurate views (and) opinions about the Rwandan context (S3.17).

- Yes, negative and biased articles on my country and government upset me (S3.18).

This encouraged the students to realise the importance of publishing their research. The Centre had a workshop on publishing and some have already published their work.

\section{My Reflections}

As a South African i was impressed by the many positive things students exchanged and Rwandans were doing in general. This made me reflect and explore what we as South Africans could learn and emulate. One of the many events $\mathrm{i}$ had witnessed was the reconciliation between perpetrators and victims. Genocidaires (convicted prisoners guilty of genocide) built houses for the children of their victims. Poor women (both groups of victims and perpetrators) because of their poverty and need to feed their children, worked 
together to form cooperatives as Marie Odette Kansanga Ndahiro's and Jane Umutoni's data $^{5}$ reflected. This impressed me deeply.

During my interrogation while in solitary confinement in SA during apartheid my interrogator proudly announced he would serve in the new government that would inevitably happen as the signs were there that the apartheid regime's days were counted. I immediately mentioned the need for a Nuremberg type trial. He arrogantly retorted that no human rights violations have been committed in SA. I challenged him, highlighting the fact that he was an Afrikaner white male, which gave him great power and many privileges in apartheid SA. I added that he was either so obtuse or denied that he did not know that what he was doing to me was a human rights violation. Subsequently post-1994 in SA we had the Truth and Reconciliation Commission (TRC). He did not consider it necessary to go. As many will attest, despite being internationally lauded, it had mixed results. The Amnesty section worked more effectively than the Reparations one. Millions had suffered gross human rights violations, yet they are still not classified as victims. The TRC lasted for 10 years and identified only 1,700 of us listed with the TRC as victims. One of the key recommendations of the TRC is that the process of identifying victims of gross human rights should continue. This has not yet happened. Khulumani Support Group of which i was a board member is working towards and advocating for the incomplete work of the TRC to be finalised.

I am privileged to be one of the 1,700 that are classified as 'victim of gross human rights' and i receive a special monthly pension. Our treason trial of 14 persons is a microcosm of the new SA. Post-trial only six of us had privileged employment and four of these were as members of parliament and have had political appointments. Two were fairly comfortable within their families but the rest really struggled to get employment. One still has not have employment since the treason charges had been dropped in 1990 .

The class discussions and witnessing the events in Rwanda made me realise the importance of reconciliation. Perpetrators met victims asking for forgiveness, shared experiences and worked towards reconciliation. I decided that during my holidays to SA i would try to speak to my interrogator. I had a few questions that $\mathrm{i}$ would like to pose to him and hoped that through this interaction some understanding and reconciliation would result. I was also encouraged about the possibility of meeting with him when i learnt about how another South African Apartheid Lieutenant Mostert (a very notorious Security Policeman during the 1980s) had approached political activist Johnny Issel to meet and asked for forgiveness. Johnny Issel was a grassroots political leader who had been terrorised by Mostert. When i learnt about the Mostert visit and apology i was heartened. I believed in sharing this news with the Captain, he may be encouraged to follow Mostert's example and agree to our meeting.

Captain Andre Du Toit did not want to meet or have any form of interaction with me. He justified through writing a three page email why he did not want 
to be interviewed. He gave me permission to use the email in my writing. Of course, i should forward my text to him before publishing. What is marked though is that as a beneficiary of apartheid and who worked to maintain the apartheid system, he does not make any reference to this or the negative implications of doing this. He believes he 'served both regimes faithfully, the former under the Nationalist apartheid Party and secondly under the African National Congress'. He is now 'doing his bit for the new SA' as he is 'lecturing mainly to blacks in Criminal Law'. He further added: Apparently I must have done some things correctly, as I was promoted to [a very senior] rank ... in the ... Province. He has been promoted to general.

My responses: Immediately, $\mathrm{i}$ think of the enormous pension he gets. In terms of reparations and dignity of the victims, i think of my co-trialists and to what extent some of them are living in dire poverty and unemployment. What is also remarkable, though, like most beneficiaries of apartheid, he does not take any responsibility for the past. Instead he still refers to '(the) involvement in the criminal actions you and others engaged in during the so-called Rainbow Trial' (my emphasis). He refers to our 'criminal actions' even though none of us had been found guilty, as all the charges had been dropped in December 1990.

\section{Conclusions}

TJ was not an academic subject but gave my students and me an opportunity to explore the context of our lives, what was happening in our countries and what needed to be changed and resolved. The course material encouraged selfreflection and our roles and contributions to building a new society. What was remarkable was the fact that students mentioned their commitments to provide positive inputs into their homes, communities and the country in general.

According to the Kigali Institute of Education's (where the Gender Centre was housed) evaluation 94\% strongly agreed that the learning outcomes were clear and that they had opportunity to actively participate in the module. In the overall evaluation, comments included: 'It is the most interesting module I learn in the master's' (p. 5); 'more time' (p. 5); 'I recommend this module for all university students' (p. 8). Other concerns were 'Too many assignments' (p. 8); 'Outline of course to be given before the course' (p. 8).

The fact that we did country cases and that i highlighted the parallels and polarities between Rwanda and South Africa gave an added irony to our analyses of these countries. ${ }^{6}$ There were many positive experiences that South Africa could emulate; one being the structured memorial time as in Rwanda.

There are many positive aspects that can be learnt from Rwanda. Because of the umuganda tradition (monthly cleaning up) Rwanda is billed as the cleanest African country. The parents' evenings (umuhira) are devoted to parents discussing gender equality in the family. The agaciro (dignity) fund has been in place for some years. It is a project through which Rwandans all contribute to 
general development in order to lessen their dependence on external funding. But it was fast-tracked in November 2012 when countries like the United Kingdom, France, the Netherlands and the United States of America, amongst others, immediately stopped their funding because of Rwanda's alleged support of the rebel Congolese group, M23, in the Eastern DRC. This has since been disproved. Each person and public institution took decisions about how much they were to donate monthly. Most decided on $10 \%$ of their month's salary. In our case, our university decided on $30 \%$. People still willingly continue to pay this. It has been an inspiring experience for me to teach and live in Rwanda.

\section{Notes}

1 I consciously use the small letter for the first personal pronoun ' $i$ ' throughout this text. In Afrikaans which we speak, as well as many other languages, a small letter is used for the first person singular. I hence choose to follow this example as it also reminds me to remain humble. The exception is when $\mathrm{i}$ start a sentence with it i will use the capital letter.

29 July 2011.

3 This process was protracted through a number of classes. I was mindful not to focus too much on the student for a long time during one lesson. This could also have been embarrassing to the student.

4 Two of many possible examples include Senier (2008) and Rombouts (2004).

5 Ndahiro (2012) and Umutoni (2012).

${ }^{6}$ In both countries April 1994 was a turning point in their respective histories; Rwanda experiencing the genocide until 4 July 1994 and South Africa the apprehension and later celebration of successful first democratic elections.

\section{References}

Kansanga Ndahiro, MO 2012, The 1994 Rwanda Genocide against Tutsi Memories and the lives of raped Tutsi Women. Thesis submitted to the Centre for Gender Culture and Development, Kigali Institute of Education, 2012.

Rombouts, H 2004, Victim Organisations and the Politics of Reparation: A case study on Rwanda. Intersentia, Antwerp.

Senier, A 2008, Traditional Justice as Transitional Justice: A Comparative Case Study of Rwanda and East Timor, Praxis: Fletcher Journal of Human Security, vol. 23, 67-88.

Umutoni, J 2012, Tools of Nurturing Women's Entrepreneurship and Promoting Reconciliation in Post-Conflict Rwanda: Buranga Women's Cooperative. 
Thesis submitted to the Centre for Gender Culture and Development, Kigali Institute of Education, 2012.

\section{Contributor Biography}

Gertrude Fester-Wicomb, an anti-apartheid activist, was part of the Women's National Coalition that contributed to gender-sensitivity in the SouthAfrican Constitution. Like many political prisoners she was an MP in the new democratic government. Academic positions include Professor Extraordinaire (Western Cape University), Wynona Lipman Chair (Centre for American Women and Politics, Rutgers, USA), Professor in Transitional Justice (Rwanda) and Sociology (Sol Plaatje University). Currently PhD supervisor (Bishop Stuart University, Uganda) and Honorary Professor (Centre for African Studies, University of Cape Town). 